\title{
Distribution and glaciological implications of relict surfaces on the Ultevis plateau, northwestern Sweden
}

\author{
Anders Glarhäll, Johan Kleman \\ Department of Physical Geography, Stockholm University, S-106 91 Stockholm, Sweden
}

\begin{abstract}
The Ultevis plateau, northwestern Sweden, has a relief of less than $200 \mathrm{~m}$, yet bears three different kinds of landscape, classified according to the degree of glacial erosion. The first type is restricted mainly to topographic highs and has almost entirely escaped erosion, despite complete and prolonged ice cover during the late Weichselian. The other two landscape types are distinguished depending on whether older landforms have been completely erased or not. The latter two appear to have undergone erosion only briefly. The transitions between landscape zones are usually sharp, and specific boundary landforms occur. The Scandinavian ice sheet was cold-based in its central areas during its maximum. During the deglaciation, both the dry/wet-base boundary and ice margin migrated inwards, at different speeds. When the ice front retreated faster than the thermal transition zone, the wet-base marginal zone shrank and erosion was reduced or avoided. Where the wet-base zone was of limited longitudinal extent, as on the Ultevis plateau, conversion from a frozen to a thawed bed was incomplete, leaving a patchwork of preserved glacial and non-glacial morphologies.
\end{abstract}

\section{INTRODUCTION}

Several examples of landscapes and landforms indicating surprisingly weak glacial erosion have been reported in Sweden during the last ten years (Lagerbäck, 1988a, b; Rodhe, 1988; Kleman and Borgström, 1990, 1994; Hättestrand, 1997). These areas are relict, in the sense that they have been covered by the late Weichselian ice sheet, but nevertheless have not been significantly modified glacially. Instead, they display subaerially developed landscapes, or glacial landforms from ice sheets predating the late Weichselian. Such areas with relict landforms range in size from less than one to hundreds of square kilometres and occur in the high relief of the mountain chain, as well as on the hilly plains of northern Sweden. Similar relict landscapes and landforms have also been observed in the northern and eastern maritime parts of the Laurentide ice sheet area (Dyke and others, 1992; Grant, 1994). In most cases, sustained frozen-bed conditions have been invoked as the cause for non-erosion and preservation. When the basal ice is below the pressure melting point, the interfacial adhesion between ice and rock is strong and shear takes place in the ice itself (Boulton, 1972; Hughes, 1973; Sugden, 1978).

Kleman and Borgström $(1990,1994)$ presented mapping and interpretation of relict surfaces at the scale of individual relict patches. Owing to the fragile nature of the preserved landforms in the considered cases, it was thought highly unlikely the surfaces had experienced any period of wet-bed conditions and basal sliding. Hättestrand (1997) and Kleman and others (1997) presented maps of the distribution of relict landscapes on the regional and ice-sheet scales. On those regional-scale maps of relict landscapes, the conceptual framework is slightly different; the maps demonstrate areas with preserved older landscape elements, mostly of substantial size (early Weichselian Veiki moraine or eskers) and robust nature (large early Weichselian or older drumlins and cragand-tails). The presence of those landscape elements demonstrate that erosion by the late Weichselian ice sheet was very small, but in contrast to preserved ground surfaces with relict patterned ground they may have survived brief periods of wet-bed conditions and basal sliding.

The significance of the relict surfaces lies in their potential to shed light on an otherwise elusive glaciological parameter, the basal thermal conditions of former ice sheets. Regional mapping of relict surfaces may thus significantly aid numerical ice-sheet modelling, and in particular icethickness estimates, by providing data necessary for tuning such models. We present detailed mapping of relict surfaces and intervening glacially reshaped areas over a hilly area of about $750 \mathrm{~km}^{2}$ which straddled the boundary zone between a fully frozen-based up-ice region and a mostly or fully wetbased down-ice region during the final decay of the Fennoscandian ice sheet. We focus on the spatial organization of the relict surfaces, the relative chronology of the landforms in the area, and the palaeoglaciological inferences that can be drawn from the reconstructed sequence of events.

\section{METHODS AND RESULTS}

The morphology of the Ultevis plateau was interpreted from colour infrared aerial photographs at a scale of 1:60000. From the aerial photographs, glacial landforms and relict surfaces were mapped. This mapping was verified during two weeks fieldwork and stratigraphy was determined at a key site on Tjate Hill. Helicopter reconnaissance was carried out over the area twice. Only landforms considered important for reconstructing ice-sheet behaviour and the extent of the relict surfaces were mapped. 


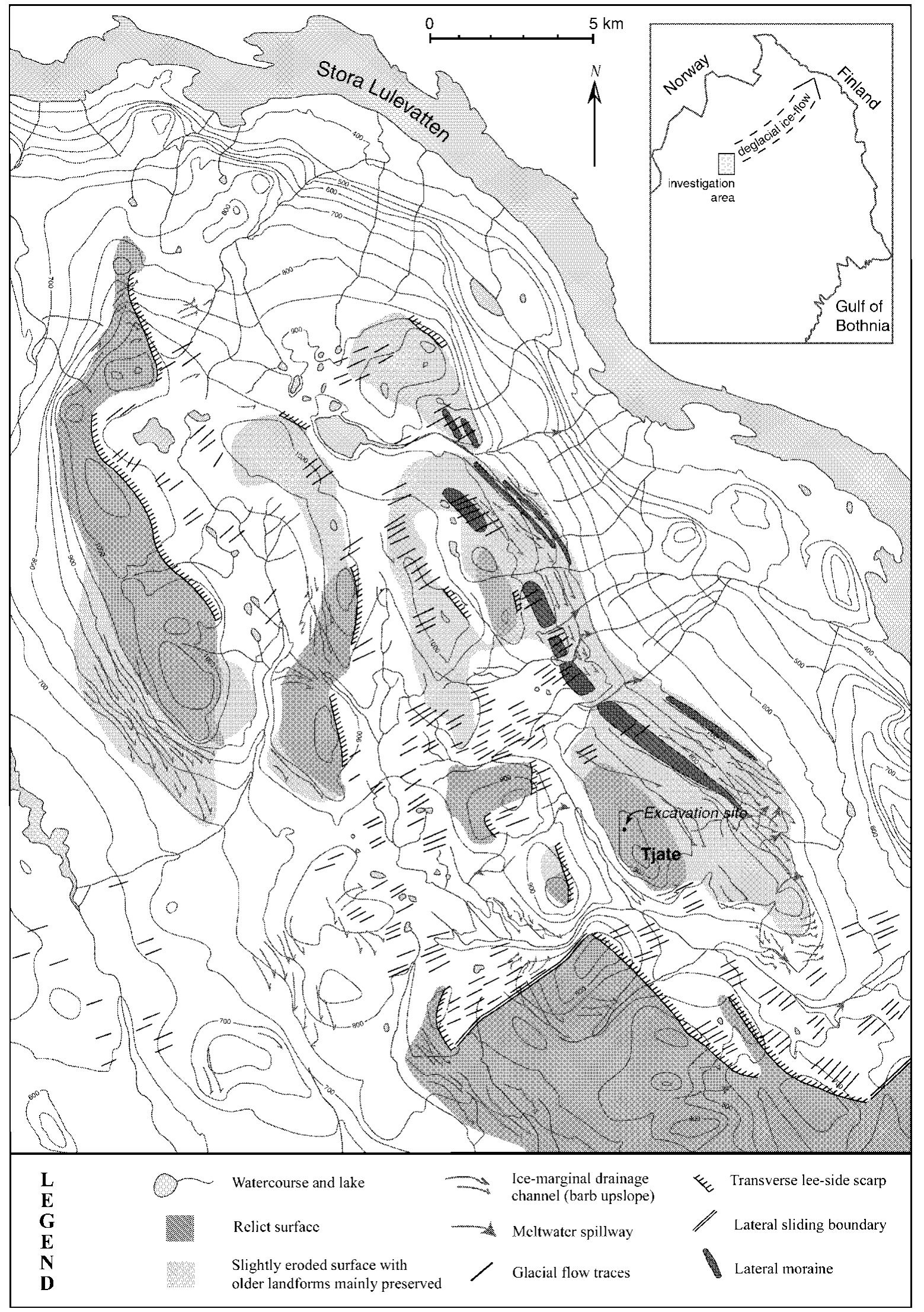

Fig. 1. Glacial geomorphology of the Ultevis plateau.

\section{Morphology of the Ultevis plateau}

The Ultevis plateau is a gently undulating mountain plateau at $800-1100 \mathrm{~m}$ a.s.l (Fig. 1). It is tilted slightly towards the south-southeast and has a local relief of 100-150 m. The bedrock is mostly composed of Precambrian porphyrites.
Quartzites occur in the southwestern part of the mapped area (Kulling, 1977). None of the mapped glacial-geological boundaries conform to any known bedrock structures or boundaries. The hills on the plateau surface are generally elongated in a north-northwest-south-southeast direction. The dip of the plateau surface and the topographic grain is 


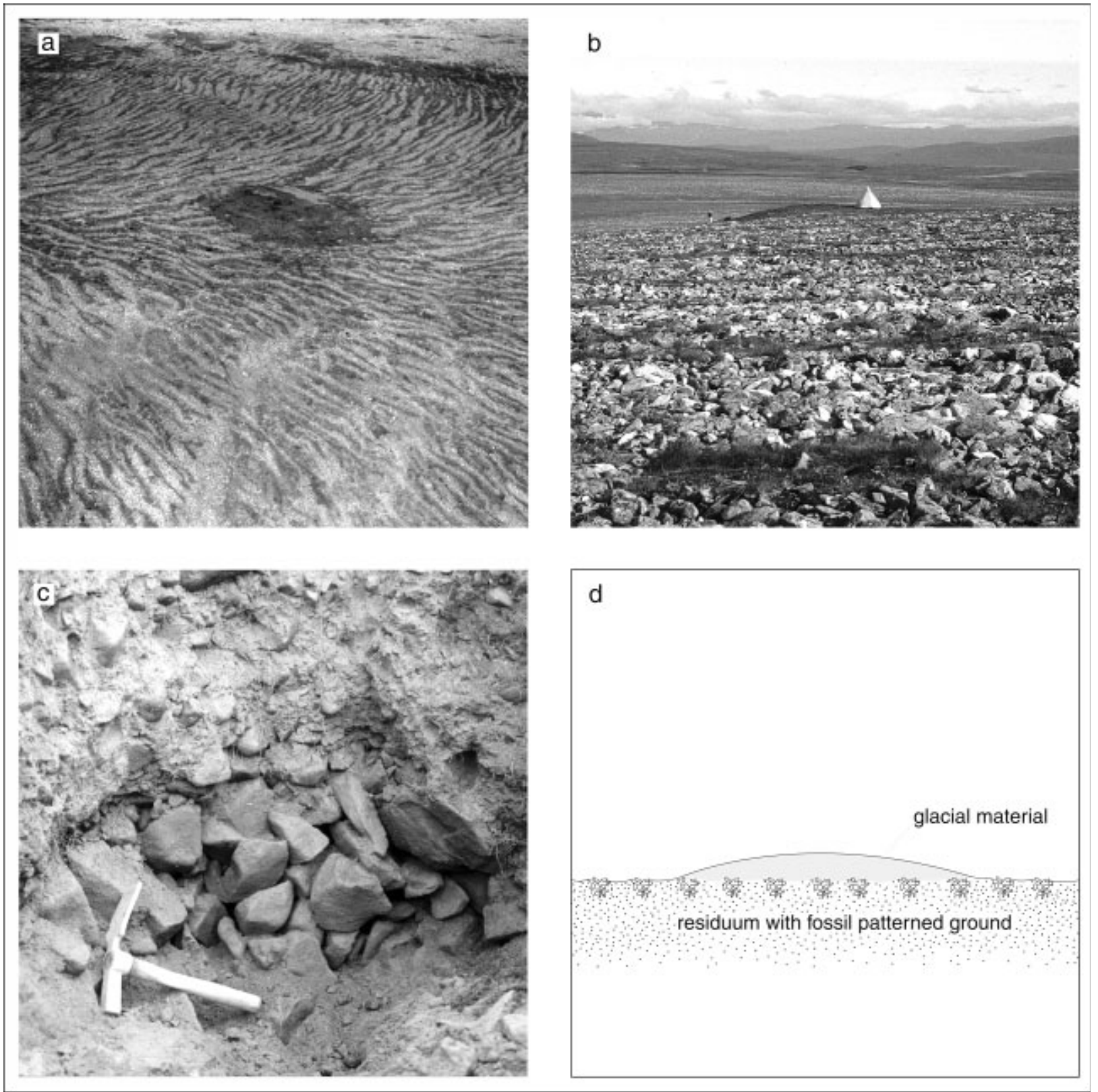

Fig. 2. Mound of glacial material superimposed on fossil patterned ground. (a) Oblique aerial photograph. (b) Ground view. (c) Stratigraphical section. Lower part is a buried stone stripe. Voids between stones are not filled in with fine material. Topmost part is glacial material of the overlying mound. (d) Cross-section of glacial mound with underlying stone stripes.

transverse to the latest recorded ice-flow direction towards the northeast. This relationship has, as will be described later in this section, some implications for the distribution of the relict surfaces. The area bears many characteristics of a preglacial landscape such as described by Gjessing (1967) from southern Norway: convex-concave profiles, round summits, wide shallow valleys and open passes. Steep slopes, glacially incised valleys and lake basins are not generally present. The glacial reshaping is minor and restricted mainly to the lower parts of the plateau surface. Most of the hills are featureless and covered with sorted polygons, sorted stone stripes or boulder fields (Hoppe and Melander, 1977). Where inspected in the field, these periglacial surfaces were composed of locally derived, stony, monolithological material. No permafrost was encountered in a $1.5 \mathrm{~m}$ deep pit. Where glacial reshaping has taken place on the plateau surface, the ground is covered by a thin fluted or moulded till blanket. There are no eskers or other evidence of substantial subglacial drainage.
Some of the preglacial surfaces have a slight glacial imprint. Older landforms, glacial or non-glacial, are preserved in that they are still discernible morphologically, but have been slightly reshaped, in most cases by faint fluting. These areas are represented in Figure 1 by a light grey tone. They typically form extensions of the true relict surfaces.

Virtually no periglacial sorting phenomena were observed to have developed in the fluted or drumlinized areas (of late Weichselian age) during postglacial time. The only ones noted were stones circles at lake shores, where the water table was close to the ground surface. Hence, the impact of Holocene periglacial processes in the area appears to have been extremely limited.

\section{Characteristics of the relict surfaces}

The relict surfaces at Ultevis are characterized by residual soils, patterned ground and ventifacted boulders. Landforms 
diagnostic of glacial erosion, such as lineations, lake basins, marginal moraines and glacial facets, are not present. The surface is smooth and bedrock outcrops are rare on the hill summits. The well-developed patterned ground, in the form of sorted polygons and boulder stripes, is an important diagnostic criterion for the relict surfaces. The patterned ground and fluting spatially are mutually exclusive, which would not be the case if the development of the patterned ground postdated the fluting.

Sparse, but well-established vegetation of grasses, mosses and dwarf birch grows in the finer material between boulder stripes. The individual boulder circles and stripes are hardly visible in the aerial photographs, but the regular pattern of boulders and the sparse grass cover on the fine material creates an easily discernible spotty, velvety texture in the aerial photographs. This texture is an important marker when mapping the relict surfaces in aerial photographs.

\section{Landforms within the relict landscape and relative ages}

On Tjate Hill (Fig. 2a and b), the regular pattern of boulder stripes is disrupted by a mound of glacially derived debris. The mound is about $2.5 \mathrm{~m}$ high and $20 \mathrm{~m}$ in diameter and is situated on the southwestern slope, about $100 \mathrm{~m}$ from the crest of the elongated hill, at an elevation of approximately $950 \mathrm{~m}$ a.s.l. No permafrost was encountered in a $1.5 \mathrm{~m}$ deep pit which was dug close to the edge of the mound. Stratigraphical investigations of the site show that the mound sits on top of the patterned ground and consists of material different from the underlying residuum. The material of the mound is a coarse sediment with a greyish matrix of coarse sand. Rounded cobbles, up to $150 \mathrm{~mm}$ in size, are frequent. The lithological composition of these stones is very diverse. A simple stone count of 100 stones gave 25 different lithologies. Not a single cobble consisted of the porphyry that constitutes the local bedrock. The mound material does not show any surficial signs of cryoturbation processes. Beneath the mound, the material is similar to the ground surface surrounding the mound; a reddish residuum with angular boulders. The boulders have a monolithological composition of porphyry with the sorted stripes still well preserved. In the excavation pit, we found two buried boulder stripes and intervening coarse sand. The transition between the two units is sharp and the voids between the boulders are still open and not filled in with the superimposed glacial debris (Fig. 2c). We regard the glacial mound on Tjate Hill as very strong support for a pre-late Weichselian age of the mapped relict surfaces. As formation of patterned ground implies ice-free conditions, and as the mound is a clear sign of later glacial transport into the area, the patterned ground must be inherited from an earlier interstadial or interglacial. These features are fragile and would easily be destroyed if basal sliding occurred even during a very brief period. We suggest that the material was transported englacially into the area, which under frozen-bed conditions could occur without destruction of the basal interface.

The only other major glacially related mechanism that can be traced on the relict surfaces is the action of marginal meltwater run-off. The imprint of glacial meltwater exists in the form of well-shaped lateral meltwater channels, which are in agreement with the concept of cold-based ice (Sugden and John, 1976; Sollid and Sørbel, 1988; Dyke, 1993; Kleman and Borgström, 1996). As meltwater cannot penetrate cold ice, the water runs alongside a glacier tongue cutting a channel into the hillside. This mechanism only occurs when the ice is so thin that the hills protrude above the glacier surface. Between the channels, the ground bears no sign of glacial modification. The lateral channels are incised in residuum in several localities, similar to relationships described by Kaitanen (1969) and Dyke (1993) and thus demonstrate that those deposits are not postglacial.

Lateral channel systems occur in two different generations on the Ultevis plateau. The most extensive system was created by a southeast-flowing ice sheet with a margin generally retreating towards the northwest. Because of the funnelling effect of the valleys, the meltwater was steered along the flanks of the northwest-southeast trending hills. These channels are in many places cross-cut by a younger system indicating drainage towards the northeast. The older southeast-trending channels fit well to the reconstruction by Kleman and others (1997) of the early Weichselian ice sheet. The subdued appearance of these features also suggests they are of considerable antiquity. One of these localities, in the southeastern part of the investigation area, was described by Rodhe (1988). Other evidence for a major southeasterly ice flow is a group of very large lateral moraines on the northeastern slope of the Ultevis plateau (Fig. 1). These moraines can, with the exception of minor gaps due to stream erosion, be followed over $15 \mathrm{~km}$ and are, in part, at least $30 \mathrm{~m}$ thick. They were created by lateral deposition by an outlet glacier draining an older mountain-centred ice sheet. Erosion during the last deglaciation reshaped the top of the moraines slightly and left a faint fluting at right angles to the lateral moraines. Based on this direction, the fluting must be linked to the deglacial phase as it can be traced further down-ice, where it also conforms to the deglacial esker pattern (Kleman, 1992; Hättestrand, 1998).

\section{Landforms bordering the relict surfaces}

Kleman and Borgström (1994) described transverse lee-side till scarps as a landform frequently occurring at the transition between an up-ice frozen-bed patch and a distal thawed zone. Such transverse lee-side till scarps are frequent in the Ultevis area. Since there is reason to believe that plucking on the lee side of hills can occur, and has occurred, in any type of loose deposit, we henceforth use the broader term "transverse lee-side scarp".

A lateral sliding boundary separates a zone of subglacial lineations from adjacent areas with morphology (till lineations) indicating a completely different ice-flow direction, or displaying relict non-glacial morphology. The very narrow transition (10-50 m) found at many locations (Kleman and Borgström, 1994) is easily detected in aerial photographs, but may be difficult to discern in the field. Two lateral sliding boundaries have been identified in the investigation area. The first one is at Mount Tjuolma, where it separates a relict area with patterned ground and old meltwater channels from the late Weichselian drumlinized landscape (Kleman, 1992). The drumlinoids cut across the old meltwater channels and have partly destroyed them, but the channels are still discernible between the drumlin ridges. The other lateral sliding boundary is situated in the southeasternmost part of the investigation area. Like the Tjuolma boundary, this one is sharp and separates two landscapes with different textures; a relict smooth surface and a late Weichselian eroded surface (Fig. 3). Like the lat- 


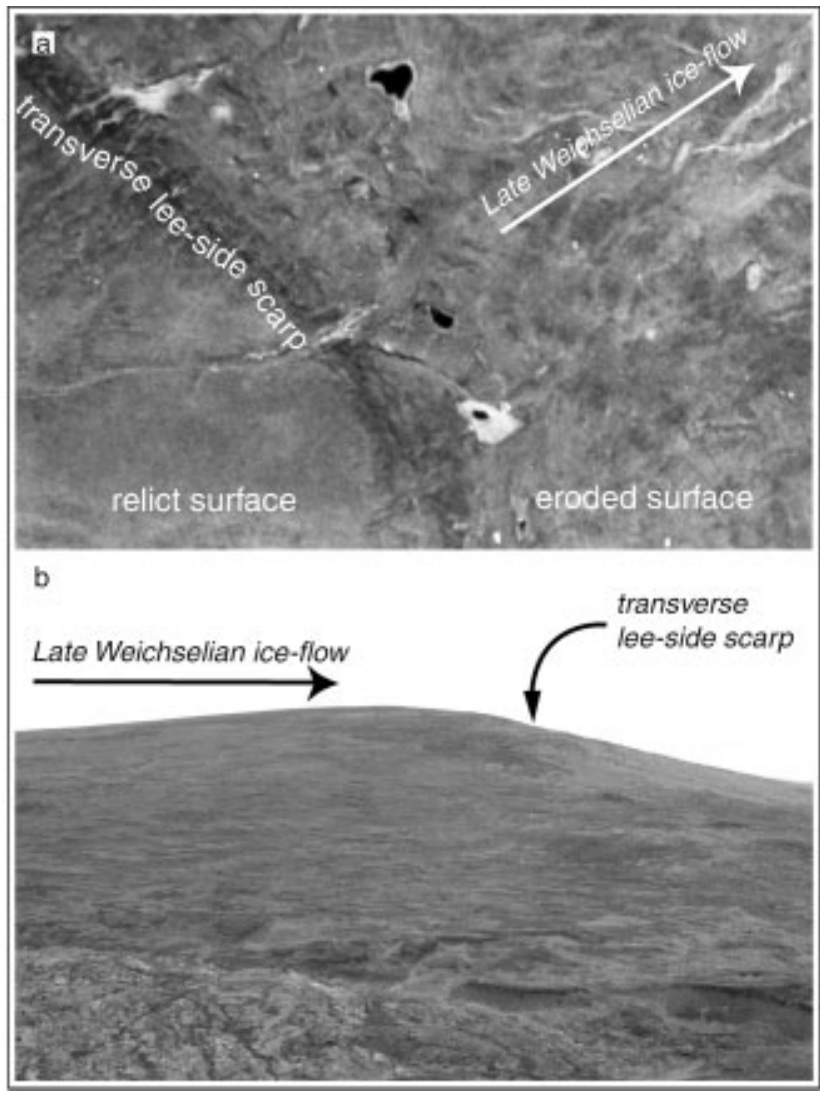

Fig. 3. Transverse lee-side scarp. (a) Vertical aerial photograph showing relict surface (lower left) and eroded surface (upper right). (b) Ground view of transverse lee-side scarp. On distal side (right) is a blanket of boulders tranported in the ice-flow direction.

eral boundaries described by Dyke and Morris (1988), those on Ultevis do not coincide with any abrupt change in slope.

Transverse lee-side scarps are numerous on the Ultevis plateau. Most hills show a sharp break in texture on the northeastern slope, which constitutes the proximal end of the relict surface. This break is the actual scarp, often made up of a step in the ground surface down to the weathered bedrock. Distally, the material from the scarp has been drawn out as boulder blankets or flutes, in the direction of ice movement. The boulder frequency diminishes in the inferred direction of flow.

\section{DISGUSSION}

With these results, we have demonstrated that relict surfaces exist and can be identified. Direct evidence for pre-last-icesheet age of relict surfaces is the presence of subaerially developed landforms that have escaped major erosion in the older overridden landscape, ranging from very large lateral moraines (10 km scale) and marginal channels ( $\mathrm{km} \mathrm{scale),}$ to fragile patterned ground ( $\mathrm{m}$ scale). Depositional evidence is the mound of glacial debris on Tjate Hill superimposed on patterned ground.

\section{Formation of lee-side scarps}

Transverse lee-side scarps are very conspicuous landforms of an ice-sheet bed with mixed temperature characteristics. They constitute most of the distal boundaries of the relict

patches in the area and offer an opportunity to study the very sharp break in texture between relict and eroded surfaces. The formation mechanism for these scarps is far from clear. When they formed, a frozen patch existed immediately up-ice and there must have been minimal basal water present at the location of the scarp. We suggest that the area immediately down-ice of the transverse scarps did not experience true wet-bed conditions. Rather, the coupling between soil and bedrock became weak when the phasechange surface (PCS) rose to the soil-bedrock interface. The decreased effective pressure on the lee side of topographical highs facilitated brittle fracture and plucking of the still-frozen till sheet. Direct evidence for wet-bed conditions, such as true moulding of the till sheet, is only found slightly lower in the terrain and at some distance from the scarps.

\section{Importance of convergence-divergence patterns for basal temperature}

Glasser (1995) modelled the temperature distribution for a transect of the Scottish ice sheet. He stressed that the bed topography was critical in determining the location of areas of basal melting. Increased strain heating from convergent flow in lower areas caused the temperature to rise to the melting point. At Ultevis, an area of more gentle relief, convergence of flow does not seem to be as important. If strainheating led to streaming, the relict patches should be elongated in the direction of flow, but no such pattern is apparent in Figure 1. Instead, the elongation of individual patches is governed by the topography. Furthermore, the flow traces should be divergent on the up-ice side of the relict patches and convergent on the down-ice side. No such pattern is to be found in the area.

Table 1. Sequence of events at the Ultevis plateau

Non-glacial events Glacial events

Holocene subaerial processes (minor)

Periglacial surface processes (patterned ground in all topographic positions). May have been formed during multiple cycles

Subaerial development of gross morphology (represents multiple cycles and long time-span)
Formation of marginal channels during final deglaciation

Partially wet-based zone transgressing into the area during final icesheet decay (ice flow from the southwest)

Ice divide migrates westwards, over the area

Sustained non-erosive ice cover (ice divide east of the area)

Formation of lateral moraines and marginal channels (decaying early Weichselian or older ice sheet with outlet glaciers, ice flow from the northwest) 


\section{Sequence of events (Table 1)}

The first early Weichselian ice sheet left a significant glacial landform record. Previous glacial deposits were largely eroded and redistributed (Lagerbäck, 1988b; Kleman and others, 1997; Hättestrand, 1998). Landforms on Ultevis that can be ascribed to that stage are the large lateral moraines and the southeast trending lateral drainage channels. The early Weichselian ice sheet did not necessarily erode the higher parts of the landscape. The non-glaciogenic properties of the hilltop soils, and the direct evidence of later icesheet overriding, implies they could be pre-Weichselian in age. However, the patterned ground in these soils developed its present appearance during one or more Weichselian interstadials. During the middle Weichselian and the major part of the late Weichselian, the area was covered by cold-based ice and no reshaping took place. During the Last Glacial Maximum (LGM), the ice divide was situated far out in the Gulf of Bothnia and, as the deglaciation proceeded, it migrated westward towards its last position in the Scandinavian mountain chain (Ljungner, 1949; Kleman, 1992). There is no imprint of this ice flow expected from the east during the LGM, but from the latest stage, when the ice divide had moved over the area to a westerly position. The ice flow was then from the southwest. The glacial imprint at this last stage is strongly associated with a partly melting bed. As the ascending PCS met the bed at the lower parts of the terrain, valleys were the areas that first experienced basal melting and glacial erosion, in line with glaciological theory (Hughes, 1981). A continuously rising PCS would eventually lead to a completely thawed bed, but hilltops would remain cold-based the longest. At Ultevis, the rising of the PCS probably continued until the ice-marginal retreat exposed the area. No more signs of glacial erosion can be seen in the up-ice direction (Hättestrand, 1998), which is interpreted to reflect fully frozen-bed conditions on the eastern side of the last ice-sheet remnant. The distance to the last ice divide was less than $70 \mathrm{~km}$.

The short duration of active erosion can also explain the only slightly eroded surfaces, where older landforms are mainly preserved despite some fluting overprint.

\section{Glaciological implications}

The area we have studied appears to have been located in a transition zone between two basal thermal regimes. Further northeastward (down-ice), the landscape has experienced fully wet-based conditions and is characterized by a conventional wet-bed glacial-landform assemblage with large drumlins and eskers. Southwestward, on the up-ice side, the landscape lacks any subglacial landform record at all from the late Weichselian. For individual landform types, the transition along the northeast-southwest gradient is gradual. Eskers go from large and continuous to small and fragmented and are finally absent. Instead, lateral drainage channels are more frequent in the inner zone, suggesting that the meltwater drainage became more and more supraglacial. Drumlins undergo a similar transition from large and frequent to less significant, finally giving way to fluting and boulder blankets or boulder streaks. Despite differences in topography, this is a general pattern remarkably similar to the one reported by Dyke and others (1992) from Prince of Wales Island, Northwest Territories, Canada, where drumlins diminish in size and frequency, but relict patches of older landforms gradually become more abundant towards the head of a palaeo ice stream. Observations from other areas, such as Southampton and Baffin Islands, Arctic Canada, and Varanger Peninsula, Norway (Clarhäll and Kleman, unpublished maps) suggest that the observed "archipelago-type" boundary between frozen and thawedbed zones is a normal ice-sheet feature.

The individual relict patches on the Ultevis plateau are on the order of $1-10 \mathrm{~km}$. They are usually elongated in the northwest-southeast direction, which is in accordance with the general elongation of the hilly topography. Hence, there is no significant tendency for elongation in the ice-flow direction, although two sliding boundaries are strictly parallel to the ice-flow direction. Such lateral boundaries appear to be more abundant in terrain where the topographical grain parallels the ice-flow direction (Kleman and Borgström, 1994). We suggest that the development of positionally stable, lateral, sliding boundaries is favoured by a suitable flow-parallel topography, with the most extreme manifestation being the self-enhancing system of selective linear erosion (Sugden and John, 1976).

\section{GONGLUSIONS}

The Scandinavian ice sheet was cold-based in its central areas during its maximum. During the deglaciation, both the dry/wet-base boundary and ice margin migrated towards the Scandies. When the ice front retreated faster than the thermal transition zone, the wet-base marginal zone was eliminated and no erosion took place. Where the wetbase zone was narrow, as on the Ultevis plateau, conversion from a frozen to a thawed bed was incomplete, leaving a patchwork of glacial and non-glacial, preserved morphologies to appear during final deglaciation.

The boundary between frozen and thawed zones is in highly fragmented, low- to moderate-relief hilly terrain, with topography being the dominant control of the shape and distribution of frozen patches.

Proximal and lateral boundaries of frozen patches mark the sliding boundary at the glacier bed, but distal boundaries of the lee-side scarp type develop a short distance upice of the true sliding boundary.

Stratigraphical evidence (till mound superimposed on patterned-ground surface), as well as morphological evidence (fluting overprinted on a very large lateral moraine), attest to minimal glacial erosion during one ice-sheet cycle.

\section{ACKNOWLEDGEMENTS}

This work was funded by grants from the Swedish Natural Science Research Council and Lagrelius Fond. We owe great thanks to M. Påhlman, who was involved in the first part of this project. P. Jansson and C. Hättestrand made constructive comments on an early version of the manuscript. Constructive comments were likewise provided by J.T. Andrews and an anonymous reviewer.

\section{REFERENCES}

Boulton, G. S. 1972. The role of thermal régime in glacial sedimentation. In Price, R. J. and D. E. Sugden, comps. Polar geomorphology. London, Institute of British Geographers, 1-19.

Dyke, A. S. 1993. Landscapes of cold-centred late Wisconsinan ice caps, Arctic Canada. Prog. Phys. Geogr., 17 (2), 223-247. 
Dyke, A. S. and T. F. Morris. 1988. Drumlin fields, dispersal trains, and ice streams in Arctic Canada. Can. Geogr., 32(1), 86-90.

Dyke, A. S., T. F. Morris, D. E. C. Green and J. England. 1992. Quaternary geology of Prince of Wales Island, Arctic Canada. Geol. Surv. Can. Mem. 433.

Gjessing, J. 1967. Norway's paleic surface. Nor. Geogr. Tidsskr., 21(2), 69-132.

Glasser, N. F. 1995. Modelling the effect of topography on ice sheet erosion, Scotland. Geogr. Ann., 77A (1-2), 67-82.

Grant, D. R. 1994. Quaternary geology, Cape Breton Island, Nova Scotia. Geol. Surv. Can. Bull. 482.

Hättestrand, C. 1997. Ribbed moraines in Sweden - distribution pattern and paleoglaciological implications. Sediment. Geol., 111(1-4), 41-56.

Hättestrand, C. 1998. The glacial geomorphology of central and northern Sweden. Sver. Geol. Unders., Ser. Ca 85.

Hoppe, G. and O. Melander. 1977. Geomorphological map 28 I Stora Sjöfallet. Description and assessment of areas of geomorphological importance. Stockholm, Statens Naturvårdsverk. (PM 1207.)

Hughes, T. 1973. Glacial permafrost and Pleistocene ice ages. In Permafrost Second International Conference. North American contribution. Washington, DC, National Academy of Sciences, 213-223.

Hughes, T. J. 1981. Numerical reconstruction of paleo-ice sheets. In Denton, G. H. and T.J. Hughes, eds. The last great ice sheets. New York, etc., John Wiley and Sons, 221-261.

Kaitanen, V. 1969. A geographical study of the morphogenesis of northern Lapland. Fennia, 99 (5).

Kleman, J. 1992. The palimpsest glacial landscape in northwestern Sweden - late Weichselian deglaciation landforms and traces of older west-centered ice sheets. Geogr. Ann., 74A(4), 305-325.

Kleman, J. and I. Borgström. 1990. The boulder fields of Mt. Fulufjället, west-central Sweden - late Weichselian boulder blankets and interstadial periglacial phenomena. Geogr. Ann., 72A(1), 63-78.

Kleman, J. and I. Borgström. 1994. Glacial land forms indicative of a partly frozen bed. 7. Glaciol., 40(135), 255-264.

Kleman, J. and I. Borgström. 1996. Reconstruction of palaeo-ice sheets: the use of geomorphological data. Earth Surf. Processes Landforms, 21(10), 893-909.

Kleman, J., C. Hättestrand, I. Borgström and A. Stroeven. 1997. Fennoscandian palaeoglaciology reconstructed using a glacial geological inversion model. F. Glaciol., 43(144), 283-299.

Kulling, O. 1977. Berggrundskarta över Norrbottensfjällens södra del. Sver. Geol. Unders., Ser. Ba 26.

Lagerbäck, R. 1988a. Periglacial phenomena in the wooded areas of northern Sweden - relicts from the Tärendö interstadial. Boreas, 17 (4), 487-499.

Lagerbäck, R. 1988b. The Veiki moraines in northern Sweden - widespread evidence of an early Weichselian deglaciation. Boreas, 17 (4), 469-486.

Ljungner, E. 1949. East-west balance of Quaternary ice caps in Patagonia and Scandinavia. Bull. Geol. Inst. Univ. Uppsala 33, 11-96.

Rodhe, L. 1988. Glaciofluvial channels formed prior to the last deglaciation: examples from Swedish Lapland. Boreas, 17 (4), 511-516.

Sollid, J. L. and L. Sørbel. 1988. Influence of temperature conditions in formation of end moraines in Fennoscandia and Svalbard. Boreas, 17(4), 553-558.

Sugden, D. E. 1978. Glacial erosion by the Laurentide ice sheet. F. Glaciol., 20 (83), 367-391.

Sugden, D. E. and B. S. John. 1976. Glaciers and landscape; a geomorphological approach. London, Edward Arnold. 